\title{
Did the Rabbis Believe in Agreus Pan? Rabbinic Relationships with Roman Power, Culture, and Religion in Genesis Rabbah 63*
}

\author{
Moshe Simon-Shoshan \\ Bar-Ilan University
}

Uri just nodded and did not attempt to point out that the chosen people were not the only ones the Eternal One had put under the yolk of this gigantic empire.

$\sim$ György Spiró, Captivity ${ }^{1}$

Great Pan lives.

Cynthia Ozick, The Pagan Rabbi ${ }^{2}$

\section{Abstract}

This article presents a reading of the story of the Patriarch's meeting with the Emperor Diocletian as it appears in the late antique midrashic compilation, Genesis Rabbah. The story encapsulates the complexity of the relationship between the rabbis and Roman political, cultural and religious hegemony, showing the rabbis as both in eternal conflict with the Roman Empire and its culture and, yet, in many ways, very Roman themselves. In the second half of the article, I argue that this story presents a unique perspective on rabbinic views of both "demons" and the

* I would like to thank Katell Berthelot, Yair Furstenberg, Naomi Goldstein, Emily Kneebone, Shlomo Naeh, Michael Satlow, Michael Segal, Jeremy Simon, Bracha Shoshan, and Joshua Weinstein, who generously gave of their time and expertise over the course of the research and writing of this article. Any errors remain my responsibility alone.

${ }^{1}$ György Spiró, Captivity (trans. Tim Wilkinson; Brooklyn, NY: Restless Books, 2015) 379.

${ }^{2}$ Cynthia Ozick, The Pagan Rabbi and Other Stories (New York: Dutton, 1983) 17.

HTR 111:3 (2018) 425-450 
Olympian gods themselves. I conclude by comparing and contrasting these views with the approaches of early Christian thinkers.

\section{Introduction}

Recent scholarly interest in rabbinic sage stories has focused overwhelmingly on narratives from the Babylonian Talmud, at the expense of stories from the Palestinian Talmud (Yerushalmi) and Midrashim. When scholars do examine Palestinian stories, it is usually in the context of parallel Babylonian narratives. The Palestinian story is used as supporting material to help clarify the development and significance of the Babylonian account. ${ }^{3}$ The lack of focus on narratives from the Land of Israel is most unfortunate, if only because these stories are of inherent literary interest and are no less worthy of our attention than their Babylonian cousins. But additionally, these stories present literary scholars with opportunities not available to them in the study of Babylonian narratives. Due to the significantly greater quantity of both primary sources and scholarship, we know much more about the Greco-Roman cultural, historical, and linguistic contexts of the stories from Palestinian texts than we do about the Persian and Syriac Christian contexts of the Babylonian Talmud (Bavli). Palestinian stories thus offer the potential for more richly contextualized readings of stories from the classical Midrashim and the Yerushalmi than is generally available in the study of stories from the Bavli. ${ }^{4}$

In this article, I will explore one such Palestinian story: the account of the Patriarch's meeting with the Emperor Diocletian in Genesis Rabbah 63:8, which has yet to receive extended scholarly treatment. ${ }^{5}$ The centrality of a named Roman

${ }^{3}$ The tone has been set by the two most prolific scholars of rabbinic Sage stories, Jonah Fraenkel in the previous generation and Jeffery Rubenstein in our own. See Jonah Fraenkel, The Aggadic Narrative: Harmony of Form and Content (Tel-Aviv: Hakibbutz Hameuchad, 2001) [Hebrew]; Jeffery Rubenstein, Talmudic Stories: Narrative Art, Composition and Culture (Baltimore, MD: John Hopkins University Press, 1999); idem, Stories of the Babylonian Talmud (Baltimore, MD: John Hopkins University Press, 2010). This emphasis is also true of most other leading scholars in the field, such as Daniel Boyarin, Shulamit Valler, Inbar Raveh, and Yonatan Feintuch. One important exception to this trend is Joshua Levinson. See the works by Levinson cited in the body of this paper.

${ }^{4}$ This is, of course, not to minimize the important work currently being done to understand narratives from the Bavli in their Persian and Syriac Christian contexts. See, for example, Michal Bar-Asher Siegal, Early Christian Monastic Literature and the Babylonian Talmud (Cambridge: Cambridge University Press, 2013); Shai Secunda, The Iranian Talmud: Reading the Bavli in Its Sasanian Context (Philadelphia, PA: University of Pennsylvania Press, 2013); Geoffrey Herman, "Insurrection in the Academy: The Babylonian Talmud and the Paikuli Inscription," Zion 79 (2014) 395-407 [Hebrew].

${ }^{5}$ The only extended discussion that I am aware of is Misgav Har-Peled, "The Dialogical Beast: The Identification of Rome With the Pig in Early Rabbinic Literature," (PhD diss., Johns Hopkins University, 2013) 123-46. Har-Peled deals with some of the same issues raised here, but focuses שואלים על החיים: , [Selected Stories from Genesis Rabbah] (Tel-Aviv: Hakibbutz Hameuchad, 2000) 108-111. The story has been repeatedly referenced in historical studies. For references, see Har-Peled as well as the works cited in the course of this article. 
emperor in this story creates a particularly valuable opportunity for reading a Palestinian sage narrative in its historical and cultural contexts. In recent years, scholars of rabbinic Judaism have started to focus on the specifically "Roman" aspects of the rabbis' "Greco-Roman" context. They have begun to look at the rabbis as an example of a Roman imperial "provincial sub-elite," which defined its identity both as a part of the Roman imperial cultural and political system and in opposition to it. ${ }^{6}$ These studies have focused mostly on rabbinic legal texts and practices. Our story presents a chance to engage these questions through the study of an aggadic narrative.

The story of Diocletian's confrontation with the Patriarch in Genesis Rabbah 63:8 encapsulates the complexity of the rabbis' relationship with Roman political and cultural hegemony. On the thematic level, the story dramatizes the clash of civilizations between the rabbis and the Romans. When read against its intertextual context, this story does not present a simple conflict between good and evil, but rather suggests a series of models for understanding the places of God's chosen people and the Roman Empire in the divine historical plan. These models complement each other but also conflict. Even within their view of themselves as a unique culture destined to stand in opposition to Roman power, the authors of our story leave room for complexity and ambiguity.

The story also inscribes ways in which the rabbis were quite Roman themselves. The rabbis portrayed in our story live comfortably in a cultural and social world which they share with their Roman masters. Their own religious practices are shaped by Roman institutions and sensibilities. Even more profoundly, these rabbis live in a world inhabited by semi-divine beings who closely resemble those believed in by their pagan neighbors. The relation that they posit between these beings and the highest divine powers was in some measure more similar to the beliefs of contemporary pagan thinkers than to those of early Christian writers. The rabbis who composed and populate our story emerge as a distinctive Roman sub-culture woven into the fabric of the Roman Empire at the end of its high Imperial phase and the beginnings of late antiquity.

After presenting the text of the story and some relevant historical background, I divide this article into two parts. The first, "Rabbis versus Romans," will explicate the ways in which the story dramatizes the conflict between Rome and Israel, and contextualizes it within larger historical and meta-historical contexts. The second

${ }^{6}$ Annette Yoshiko Reed and Natalie B. Dohrmann, "Rethinking Romanness, Provincializing Christendom," in Jews, Christians, and the Roman Empire: The Poetics of Power in Late Antiquity (ed. Natalie B. Dohrmann and Annette Yoshiko Reed; Jewish Culture and Contexts; Philadelphia, PA: University of Pennsylvania Press, 2013) 1-15. Examples of this turn in the scholarship include Ishay Rosen-Zvi, "Is the Mishnah a Roman Composition?," in The Faces of Torah: Studies in the Texts and Contexts of Ancient Judaism in Honor of Steven Fraade (ed. Michal Bar-Asher Siegal, et al.; Journal of Ancient Judaism Supplements 22; Göttingen: Vandenhoeck \& Ruprech, 2017) 487-508; Natalie B. Dohrmann, "Law and Imperial Idioms: Rabbinic Legalism in a Roman World," in Jews, Christians, and the Roman Empire, 63-78 and Hayim Lapin, Rabbis as Romans: The Rabbinic Movement in Palestine 100-400 CE (Oxford: Oxford University Press, 2012). 
section, "Rabbis as Romans," will explore how the authors of the story construct a material, social, and metaphysical world that would have been quite familiar to their pagan contemporaries. I focus particularly on the figure of the daimon Argintin, and how his very name and behavior establish links between the worlds of the story and its creators, and those of mainstream Romans of the time.

\section{The Story ${ }^{7}$}

Diocletian the king was [originally] a swineherd near Tiberias.

Whenever he came near the lecture hall of Rabbi [the Patriarch], the children would come out and beat him.

Later, he became king.

He went and stayed at Paneas, and sent letters to Tiberias on late Friday afternoon, with the order:

"I command the rabbis of the Jews to appear before me on Sunday morning."

He ordered the messenger, telling him,

"Do not give them the message

until the sun is going down on the eve of the Sabbath."

When R. Samuel bar Nahman went down to bathe,

he saw Rabbi standing before the great* lecture hall [sidra'] with his face all pale.

He said to him, "Why is your face pale?"

He told him, "'Such and such' did (Diocletian) the king write to me."

"Go and bathe," he told him,

"for our Creator will perform miracles for you."

So he went in to bathe,

and Argintin [a daimon] came laughing and dancing before him.

Rabbi wished to scold him,

but R. Samuel bar Nahman said to him:

"Leave him alone, for sometimes he appears for the sake of miracles."

He [Rabbi] said to him, "Your master is in distress and you laugh and dance*!?"

He said to them, "Go eat and have a good Sabbath

(for your Creator will perform a miracle for you)

and I will set you Sunday morning (where you desire)."

At the termination of the Sabbath, after the lecture [sidra'],

he [Argintin] took them and set them before the gates of Paneas.

They [Diocletian's men] went and told him [Diocletian],

"Lo, they are standing before the gates."

He [Diocletian] said, "Close the gates."

${ }^{7}$ All translations adapted from Soncino, according to the Theodor-Albeck text, מדרש בראשית רבא [Midrash Genesis Rabbah] (ed. J. Theodor and Ch. Albeck; 3 vols.; Jerusalem: Wahrman, 1965) 2:688-690. Major variants from MSS Vatican 30 and 60 are noted here. Parentheses mark words which appear only in Theodor-Albeck. Words followed by an asterisk appear only in the Vatican MSS. Words in square brackets have been added for clarity. This story appears in a shorter version in Yerushalmi Terumot 8:4, 46b-c. Many of the literary phenomena as well as the relevant context that I will address here are absent from the Yerushalmi. 
He [Argintin] took them and set them upon the wall of the town.

They told him [Diocletian] and he said,

"I command that the baths be heated for three days,

then let them go and bathe therein and then appear before me."

They went and heated the baths for three days,

but Argintin went and tempered the heat for them.

They entered, bathed, and appeared before him.

He [Diocletian] said to them [The Patriarch and R. Samuel bar Nahman],

"Because you know that your God performs miracles on your behalf, you disparage the king!?"

They said to him,

"Diocletian" the swineherd we did indeed insult, but to Diocletian the emperor we are loyal subjects,"

"Even so," [replied Diocletian,]

"you must not admonish even a minor Roman

or a low ranking military servant." 9

\section{Historical Context}

Before proceeding to a literary analysis of our story, I present some historical background regarding the central figures and locales described in our story. My purpose in presenting this information is not to evaluate the historical accuracy of the story. At most, the story may preserve a memory of Diocletian staying at Paneas and of his meeting with the Patriarch. It is plausible that such a meeting could have occurred, but we have no direct evidence for it. Rather, I am presenting this historical background because the authors of our story clearly presumed some basic knowledge on the part of its audience about the significance of the people and places mentioned. Of course, we cannot know exactly what the authors and original audience would have known about these people and places. But by supplying some basic historical information, I hope to give modern readers a sense of how ancient audiences would likely have responded to key elements of the story and thereby to facilitate an understanding of how the characters and settings of the story function as literary and cultural signifiers within the structure of the narrative.

It is important to note that we do not know when this story was composed. It could have been written anytime between the late third- or early-fourth-century, when the story is purported to have taken place, and the fifth-century when Genesis Rabbah is believed to have been edited. Given the story's implicit linkage between the Roman Empire and pagan culture and belief, an earlier date, prior to the Christianization of the Empire, is more likely.

\footnotetext{
${ }^{8}$ Most MSS both here and in the Yerushalmi present a shortened version of the Emperor's name here, apparently referring to Diocletian's name before assuming power, Diocles.

${ }^{9}$ The word galyyar is generally understood as an Aramaic version of the Latin galearius, a type of military servant. On this term, see Jonathan Roth, The Logistics of the Roman Army at War: 264 $B C-A D 235$ (Leiden: Brill, 1999) 108.
} 


\section{A. Paneas and Tiberias}

Caesarea Philippi was founded by Phillip the Tetrarch, son of Herod the Great, around $1 \mathrm{BCE}$ to serve as his capital. Phillip named the city for himself and his patron, Augustus Caesar. ${ }^{10}$ By the time our story is presumed to have taken place, the town was predominantly pagan and had a highly Hellenized character. It was not only a local administrative and commercial center but also a cultic center dedicated primarily to Pan as well as to other Greco-Roman gods, including the cult of the emperor. ${ }^{11}$ Due to the continued prominence of Pan and his shrine during this time, the city would come to be known as Caesarea Paneas. ${ }^{12}$

Tiberias was also founded by a son of Herod the Great, Herod Antipas, to serve as his capital. It too was named after a Roman emperor, Tiberius. It was later renamed "Tiberias Claudiopolis," to honor the emperor Claudius as well. By the Amoraic period, it was the leading Jewish community of the Galilee, serving as the seat of the Patriarch and the center of rabbinic scholarship in the Land of Israel..$^{13}$

\section{B. Diocletian and R. Judah Nesiah}

The Emperor Diocletian, who reigned from 284-305 CE, was one of the Empire's most accomplished rulers. He restored Rome to much of its former glory following the turmoil of the "crisis of the third-century." ${ }^{14}$ In addition to his military victories ${ }^{15}$ he instituted major economic, legal and political reforms ${ }^{16}$ Of particular relevance to our story is the fact that, as part of his effort to unify the Empire, Diocletian was

${ }^{10}$ John F. Wilson, "The Literary Sources," in Paneas, Volume II: Small Finds and Other Studies (ed. Vassilios Tzaferis and Shoshana Israel; IAA Reports 38; Jerusalem: Israel Antiquities Authority, 2008) 195-209; John F. Wilson and Vassilios Tzaferis, "An Herodian Capital in the North: Caesarea Philippi (Panias)" in The World of the Herods (ed. Nikos Kokkinos; Stuttgart: Franz Steiner Verlag, 2007) 131-43.

${ }^{11}$ John F. Wilson, Caesarea Philippi: Banias, the Lost City of Pan (London: I. B. Tauris, 2004) 38-55. See also Elise Friedland, "Graeco-Roman Sculpture in the Levant: The Marbles from the Sanctuary of Pan at Caesarea Philippi (Banias)," in The Roman and Byzantine Near East, Volume 2: Some Recent Archeological Research (ed. J. H. Humphrey; JRA Supplementary Series 31; Portsmouth, RI: Journal of Roman Archeology, 1999) 7-22; Andrea Berlin, "The Archaeology of Ritual: The Sanctuary of Pan at Banias/Caesarea Philippi,” BASOR 315 (1999) 27-45.

12 Wilson, Caesarea, 47.

${ }^{13}$ Aharon Oppenheimer, מוסדות ההנהגה וטבריה [Institutions of leadership and Tiberias], in טבריה [Tiberias: from its founding until the Muslim conquest] (ed. Yizhar Hirschfeld; Idan 11; Jerusalem: Yad Ben Zvi, 1988) 24-33; Seth Schwartz, Imperialism and Jewish Society: 200 B.C.E.to 640 C.E. (Princeton: Princeton University Press, 2001) 145-53; Ze'ev Weiss, טבריה: מייסודה עד Ancient synagogues in Tiberias and Hammath], in בתי כנסת עתיקים בטבריה ובחמת

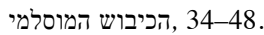

${ }^{14}$ On Diocletian's career, see Stephen Williams, Diocletian and the Roman Recovery (London: Batsford, 1985).

15 Ibid., 71-88.

${ }^{16}$ Ibid., 102-50. 
also responsible for a major revival of the traditional Roman cult and the veneration of the Olympian gods. ${ }^{17}$

The story's rabbinic protagonist is not so easily identified. He is referred to simply as "Rabbi," which generally refers to Rabbi Judah Hanasi. However, in the Yerushalmi's version of our story the protagonist is identified as R. Judah Nesiah, R. Judah Hanasi's descendant and successor, ${ }^{18}$ who is also sometimes referred to as "Rabbi." Given the setting of our story in the time of Diocletian, the "Rabbi" referred to in our text should also be identified as R. Judah Nesiah. ${ }^{19}$ Appelbaum dates R. Judah Nesiah's reign from the middle of the third century until at least its last decade, rejecting earlier claims that there were two different, shorterreigning figures who answered to this name. Appelbaum goes on to argue that this long reigning figure, the only Patriarch other than R. Judah Hanasi to carry the appellation "The Patriarch," was a particularly important and powerful member of the Patriarchal dynasty. According to Appelbaum, R. Judah Nesiah succeeded in consolidating and significantly expanding the powers of his office. ${ }^{20}$ Though R. Judah Nesiah was certainly an established scholar and the titular leader of the rabbinic estate, he was by no means the pre-eminent halakhic authority of his day. $\mathrm{He}$ is not infrequently portrayed as consulting with more senior scholars such as R. Yohanan and Resh Laqish on matters of halakha. ${ }^{21}$

\section{Part One: Rabbis Versus Romans}

\section{A. A Formalist Reading of the Story}

This historical background will enable us to appreciate better the significance of the literary structure of our story. The story depicts a conflict between two individuals, Diocletian and R. Judah Nesiah, and is set in two locales, Paneas and Tiberias, each associated with one of the characters. The drama centers on a journey that R. Judah Nesiah must make from Tiberias to Paneas to meet with Diocletian. R. Judah Nesiah and Tiberias are identified with the study and practice of Torah. R. Judah Nesiah is consistently linked with his sidra', a term which refers both to the great lecture hall in Tiberias and the Torah lectures delivered there. R. Judah is also depicted preparing for and celebrating the Sabbath in Tiberias. It is this Sabbath observance

${ }^{17}$ Ibid., 153-62.

${ }^{18}$ y. Ter. 8:4, 46b-c.

${ }^{19}$ See Theodor-Albeck's discussion of this issue in בראשית רבא, 690 n. 5.

${ }^{20}$ Alan Appelbaum, The Dynasty of the Patriarchs (TSAJ 156; Tübingen: Mohr Siebeck, 2013) 81-117. Seth Schwartz, "The Patriarch and the Diaspora," JJS 50 (1999) 208-22, takes a more minimalist view of the status of the Patriarchate in the third century. At the very least, however, R. Judah Nesiah was remembered as an important and powerful patriarch by the later transmitters and editors of the rabbinic tradition.

${ }^{21}$ Appelbaum, Dynasty, 99-104. 
that prevents R. Judah Nesiah from traveling to Paneas by Sunday morning as the Emperor commands, which generates the central tension of the plot.

Diocletian and Paneas, in contrast, are associated with the power of the Roman Empire and its nefarious designs against the Jews. Diocletian spends most of the story in his temporary headquarters in the city, sending out orders and receiving reports. He attempts first to force R. Judah to violate the Torah and then to kill him. The conflict between these two groupings thus metonymically represents a wider conflict between the Jewish people and the Torah, on the one hand, and the Romans and their empire, on the other. In light of what we have seen above, these two sets of signifiers are particularly appropriate for their assigned tasks. Diocletian and R. Judah were each the dominant national leaders of the era for their respective peoples. Tiberias and Paneas, the two former Herodian capitals, one the leading center of Jewish political and religious authority and the other a regional center of Greco-Roman culture and religion, are well cast as stand-ins for long desolate Jerusalem and far away Rome.

This analysis of the story's synchronic "deep structure" reveals the fundamental conflict between the two sides, but it does not shed light on the nature of their relationship. To understand how the story presents the dynamics of the interactions between the Jews and the Romans, we must turn to the temporal dimension of the story's plot. Reduced to its Aristotelian bare bones of exposition-crisis-resolution, we might summarize the plot as follows: R. Judah shows contempt for a Roman commoner by allowing the children to beat him. The commoner becomes Emperor and seeks to take revenge on R. Judah. In the end, R. Judah learns his lesson as formulated by the Emperor in the final lines of the story, "You must not admonish even a minor Roman or a low ranking military servant." Read in this way, the story follows a common pattern in rabbinic narratives, in which the reader follows the sage-protagonist from a state of ignorance, through a crisis, and finally to a state of enlightenment, which the sage gains through his experience. The moral that the reader learns by accompanying $\mathrm{R}$. Judah on his journey could not be clearer: it is of utmost importance to respect all elements of the Roman people and Empire. The failure to heed this teaching could be disastrous for the entire Jewish people.

From this perspective, the story advocates a pragmatic approach to JewishRoman relations. Since the balance of political and military power stands decisively in favor of the Romans, Jews would do well to defer to any and all Romans to whatever extent possible. But this reading is based on an extreme simplification of the plot's structure and the education of R. Judah which it chronicles. Much of what we have elided in this summary is a distinct plot line within the story related to the figure of R. Samuel bar Nahman. When R. Judah receives the pre-Sabbath message from Diocletian demanding his presence in Paneas on Sunday morning, his first response is panic and despair. Having provoked the wrath of the Roman emperor, R. Judah sees inevitable doom for himself, and perhaps the Jewish people as well. R. Judah's fatalistic view is in line with the larger message of taking heed 
of the vast power of the Romans. R. Samuel responds that there is no reason to worry, declaring, "The Creator will perform miracles." Later, when R. Judah is confronted by the mysterious Argintin, he similarly responds negatively, assuming the daimon is a harbinger of doom. R. Samuel reassures R. Judah that Argintin can also be an agent of divine salvation.

In each case, R. Samuel counters R. Judah's pessimism with optimism and faith. Subsequently, R. Judah and R. Samuel are indeed the beneficiaries of a series of miracles through the agency of Argintin. With Argintin's intervention, they successfully arrive at Diocletian's court by the appointed hour and then survive the Emperor's attempt on their lives. In this line of the plot, the reader and R. Judah learn a very different lesson: though at times the Roman efforts to use their power against Jews may seem unstoppable, God will miraculously intervene and save the Jews from them and their evil designs. The story thus also advocates a fundamentally theological and self-confident approach to Jewish-Roman relations that contrasts with the cautious and pragmatic view presented in the main storyline.

The two plot lines converge in Diocletian's penultimate statement, "Because you know that your God performs miracles on your behalf, you disparage the king!?" Diocletian recognizes that God protects the Jews from the wrath of Rome, but argues that this is not a reason for the Jews to disrespect the powers that be. Ultimately, the two forces in the story find themselves in a standoff. The Romans recognize that the Jews are kept beyond their reach due to divine protection. At the same time, the Jews still need to respect the power and authority of the Romans. Taken as a whole, the story appears to call for a balance between Jewish faith in the continuing engagement of God with his people, and pragmatic recognition of political realities.

\section{B. Inter-texts and Contexts}

This formalist reading of the story, despite its nuanced message, presents an essentially static picture of the Jewish-Roman relationship. It does not place the relationship into a larger historical context. It is not clear how this dynamic relates to the Jewish people's relationships with other dominant powers throughout history or with its relationship with Rome at other junctures in time. Similarly, while the story makes clear that providence continues to protect the Jewish people, its pragmatic approach to Roman power does not give much insight into Rome's place in the divine plan. A broader reading of our story, taking into consideration its place within a wider network of biblical and rabbinic texts and traditions, will reveal that this story in fact suggests a range of possible models for understanding R. Judah's encounter with Diocletian as part of the unfolding of God's historical plan for the people of Israel and the nations of the world. 


\section{The Motif of the Fiery Furnace}

The account of R. Judah and R. Samuel's escape from the scalding waters of the bathhouse of Paneas recalls the story of Hananiah, Mishael, and Azariah in Daniel 3. Having refused to bow down to an idol, these three righteous Jews are thrown into a great furnace by the Babylonian king, Nebuchadnezzar. The furnace has been specially heated at the king's orders to seven times its normal heat, just as the bathhouse of Paneas has been specially heated at Diocletian's order. A miracle occurs and the three Jews are protected from the flames by an angel, just as the rabbis are rescued by the helpful daimon, Argintin. A reader familiar with rabbinic tradition would also recall the well-known para-biblical tradition in which Abraham is saved in a similar manner after being thrown into a furnace by King Nimrod. The story is mentioned twice in Genesis Rabbah, and in both instances the midrash clearly presumes that the reader is already familiar with it. ${ }^{22}$ By referencing these narratives, our story places its events into a wider historical context. R. Judah's salvation from Diocletian is but the most recent in a series of similar miraculous occurrences in which righteous Jews are saved from incineration at the hands of wicked gentile kings. This historical pattern gives more depth to the story's lesson that God saves the Jews from the Romans.

This new message might be summed up with words of the Passover Haggadah: "For in every generation [nations] rise up to destroy us and the Holy One, blessed be He, saves us from their hands." The relationship between the Jews and the Romans portrayed in our story is thus both familiar and fleeting. There is nothing unique about the Romans. Like the great kingdoms of biblical times who made war on the Jews, the Romans, too, will ultimately pass from the stage of history while the Jewish people live on under God's protection. This gives a very different tinge to the story's message of avoiding confrontation with the Romans. It suggests not just caution rooted in fear, but patience based on the certainty that the Jews will outlast the Romans.

\section{Israel and Rome as Jacob and Esau}

Rabbinic sage stories are almost never presented as autonomous, "closed" texts. They appear as part of a larger discursive context. When these stories appear in midrashic works, this context is generally a larger hermeneutic framework through which the sage story and the biblical narrative with which it is juxtaposed mutually enlighten each other. Chapter sixty-three of Genesis Rabbah comments on Genesis 25:19-35, which tells the stories of the birth of Jacob and Esau and of Esau's selling of his birthright to Jacob for a mess of pottage. This chapter of the midrash repeatedly deploys the standard rabbinic typology identifying Jacob and

${ }^{22}$ Gen. Rab. 38:13 and 44:13. 
his descendants with the Jews, and Esau and his nation of Edom with the Romans. ${ }^{23}$ The immediate context of our story is one such application of this trope:

"Ruddy" (Gen 25:25):

R. Abba bar Kahana said:

"A shedder of blood through and through.

When Samuel [first] saw David,

'Ruddy,' as it is written,

'So they send for him [David] and brought him and he was ruddy ...'(1 Sam

16:12)

[Samuel] was afraid, 'perhaps he too is a shedder of blood.'

The Holy One, blessed be He, said to him,

'. . . with beautiful eyes,' (ibid)

Esau kills according to his own whim, (midda'ato)

But this one [kills only] with the counsel (midda'at) of the Sanhedrin."

Our story, describing Diocletian's efforts to kill the rabbis to avenge a personal slight, is cited immediately after this passage as an illustration of a Roman despot's capricious use of violence. But this identification of Diocletian with Esau and, by extension, R. Judah with Jacob has much wider implications for our understanding of the story and its portrayal of Roman-Jewish relations.

If Rome is Edom, then it is not just another in a long line of gentile kingdoms that threatened the Jews and the Torah. Rome and Israel are the "two nations" who sprang forth from Rebecca's womb, in conflict even in utero and destined by God to struggle with one another until finally "the older shall serve the younger" (Gen $25: 23)$. Rome is Israel's eternal "other" against whom Israel has defined its own identity from the outset. ${ }^{24}$

We might have expected the rabbis to contrast Israel and Rome in terms building on the biblical dichotomy, "Esau was a hunter, a man of the fields, while Jacob was a mild man who dwelled in tents" (Gen 25:27), portraying Edom as materialistically oriented and as receiving glory in this world, and Israel as spiritually oriented, receiving glory only in the next world. ${ }^{25}$ But Genesis Rabbah does not go in that direction here. As we have already seen, the midrash portrays both nations as being

${ }^{23}$ On the development of this typology and its origins in the early rabbinic period, see Katell Berthelot, "La représentation juive de l'empire romain comme pendant et frère jumeau d'Israël," Revue de l'histoire des religions 233 (2016) 163-64; idem, “The Rabbis Write Back! L'enjeu de la 'parenté' entre Israël et Rome-Ésaü-Édom," Revue de l'histoire des religions 233 (2016) 165-92. See also Ron Naiweld, "The Use of Rabbinic Traditions about Rome in the Babylonian Talmud," Revue de l'histoire des religions 233 (2016) 255-85.

${ }^{24}$ On Edom as Israel's other, see Carol Bakhos, "Figuring (out) Esau: The Rabbis and Their Others," JJS 53 (2007) 250-63. See also Sacha Stern, Jewish Identity in Early Rabbinic Writings (AGJU 23, Leiden: Brill, 1994) 18-21, and Seth D. Kunin, We Think What We Eat: Neo-Structuralist Analysis of Israelite Food Rules and Other Cultural and Textual Practices (JSOT Sup 412; London: T\&T Clark, 2004) 213-17.

${ }^{25}$ According to many rabbinic sources "dwelling in tents" refers to the study of Torah, e.g. Gen. Rab. 63:10. 
led by mighty kings who exercise temporal power. This is expressed even more clearly in a passage earlier in the chapter (63:7):

"Two nations are in thy womb":

Two celebrated among the nations are in thy womb,

One takes pride in his world

And one takes pride in his world;

One takes pride in his kingdom

And one takes pride in his kingdom.

Two celebrated among the nations are in thy womb,

Hadrian among the nations

and Solomon among Israel;

Two hated among the nations are in thy womb,

All the nations hate Esau

And all the nations hate Israel. ${ }^{26}$

What distinguishes Israel and Rome from the other nations is the greatness of their kings. Israel's most powerful king rivaled even the greatest of Roman Emperors. Israel and Rome are further distinguished from the other nations, somewhat ironically, by the fact that they are both universally despised. Israel and Rome are indeed birds of a feather.

Israel's status as a great power equal to Rome is not just reflected in its glorious past. Another passage in this chapter (63:9) looks forward to the return of the Jewish king:

A [Roman] general asked one of the house of Silna;

He said to him,

"Who will take power after us?"

He [the man from Silna] brought a piece of blank paper,

took a quill and wrote upon it,

"And after that his brother came out,

his hand grasping Esau's heel." (Gen 25:26)

In this passage the anonymous sage of the house of Silna interprets the verse describing Jacob's birth as prophesying the rise of a great Jewish kingdom on the heels of the Roman Empire. ${ }^{27}$ The interpretation demonstrates the sage's confidence that Israel is a nation of once and future kings, masters of the world, just like the Romans. On the other hand, the care with which this sage makes his claim, not even uttering the verse and certainly not his implicit interpretation of it, reflects the deep deference to Roman power also emphasized in our story.

This vision of the larger meta-historical relationship between Rome and Israel comes in a broader ideological context. As Katell Bertehlot writes:

\footnotetext{
${ }^{26}$ Note that the printed editions have a very different text from the Theodor-Albeck text presented here.

${ }^{27}$ This reading of the verse already appears in 4 Ezra 6:8-10. See Berthelot, "The Rabbis," 182-83.
} 
The Roman Empire was frequently presented by Roman or pro-Roman writers as consequent to divine providence, and its domination as eternal and expected to bring everlasting peace and blessings to the world. Such discourses represented a direct challenge to Jews living in the empire, insofar as the Roman claims to be a chosen people elected by the gods to bless the whole oikoumenè not only strongly conflicted with Jewish discourses about the election and call of Israel, but also very much resembled these Jewish claims to chosenness. One may go so far as to affirm that there was a rivalry of election and universalism between Israel and Rome. ${ }^{28}$

Berthelot goes on to describe how Philo respondes to Roman claims to be the eternal, chosen nation, favored by providence to bring blessing to the world. He argues that Rome's success is not evidence of its possession of any divine favor. In contrast, Josephus acknowledges that, like the rise of the other great empires of history, Rome's ascendancy reflected the favor of divine providence, and that Rome was God's agent for punishing the Jews. ${ }^{29}$ By adopting the Esau-Rome typology, the rabbis went even further. As Israel's doppelgänger, Rome has a unique place in the divine plan. It rules by right of Isaac's blessing, which assigns to it temporal power whenever Israel strays from the covenant. ${ }^{30}$ The end of Rome's dominance will signal the coming of the eschatological age as prophesied in Obadiah: "And the liberators will march up on Mount Zion to wreak judgement on Mount Esau, and dominion shall be the Lord's." 31

This ideological framework sheds a new light on our story. Taken on its own, the story projects an image of Jewish powerlessness and passivity. Jews are advised to take care to respect Roman power, on the one hand, and to have faith in divine intervention, on the other. R. Judah, despite his position as Patriarch, is not a monarch but rather the subject of two kings, one human and the other divine. However, read in the context of the typology of Jacob and Esau in the midrash, each being a progenitor of world-dominating kings, R. Judah's position takes on a different cast. When R. Judah stands before Diocletian, he does so as the descendant and successor of David and Solomon and the progenitor of the Anointed King to come. ${ }^{32}$ While the Patriarch currently must grovel at the feet of the Emperor, in the broader historical perspective, R. Judah and Diocletian represent monarchies of equal stature. Their very meeting has eschatological overtones, foreshadowing the final confrontation between the two kingdoms, when the kingdom of Edom will give way to the house of David.

\footnotetext{
${ }^{28}$ Katell Berthelot, "Philo's Perception of the Roman Empire," JSJ 42 (2011) 166-87.

${ }^{29}$ Paul Spilsbury, "Flavius Josephus on the Rise and Fall of the Roman Empire," JTS 54 (2003)

${ }^{30}$ See Gen. Rab. and Targumim on Gen 27:40.

${ }^{31}$ Obad 1:21. See Lev. Rab. 13:5.

${ }^{32}$ On the claim of Davidic descent for the Patriarchal line, see Appelbaum, Dynasty, 194-196.
} $1-24$. 


\section{E. The Rabbi-Antoninus Traditions}

There is one more nexus of texts with which our story has a direct relationship. Tannaitic and Amoraic literature transmit numerous traditions regarding the friendship between Rabbi Judah Hanasi ("Rabbi") and a Roman emperor named "Antoninus." 33 These narratives mostly present Rabbi as Antoninus's teacher and mentor. Antoninus asks Rabbi questions not only regarding biblical interpretation, ${ }^{34}$ halakhah, ${ }^{35}$ and theology, ${ }^{36}$ but also regarding critical affairs of state. ${ }^{37}$ Antoninus expresses his appreciation by giving Rabbi fields and other gifts. ${ }^{38}$ Rabbi in turn describes Antoninus as a benevolent monarch known for his military innovations and shows him great deference. ${ }^{39}$ Genesis Rabbah contains no less than six references to the Rabbi-Antoninus relationship. Our story's depiction of the confrontation between Rabbi's successor, grandson and namesake, and Antoninus's mighty successor recalls this earlier relationship, inviting an alternative understanding of our story. In light of the Rabbi-Antoninus relationship, the state of Roman-Jewish relations depicted in our story is hardly inevitable, nor divinely ordained. Rabbi and Antoninus represent a very different possible model for Roman-Jewish relations based on mutual respect and collaboration. The existence of such a golden age but a few generations before our story suggests a reading of the story not so much as a larger statement about Romans and Jews but rather as a specific critique of Diocletian and Rabbi Judah Nesiah. Both men failed to live up to the enlightened models of their predecessors. It is impossible to determine the historical context of this critique precisely. It may accurately reflect negative attitudes towards Rabbi Judah and Diocletian held by their rabbinic contemporaries. But it may additionally, or exclusively, reflect a retrojection of the views of later rabbis regarding the contemporary Patriarchate and Roman emperors. By the time of the redaction of Genesis Rabbah in the late fourth or early fifth century, the Patriarchate was likely estranged from the rabbinic establishment and, following the Empire's turn to Christianity, Jewish relations with Rome had taken a turn for the worse. Rabbi Judah Nesiah and Diocletian may be meant as stand-ins for their successors in a later era.

For our purposes, the important thing is the implicit narrative line drawn by the storytellers between the stories of Rabbi and Antoninus and the story of Rabbi

${ }^{33}$ For a survey of these sources, see Ofra Meir, Rabbi Judah the Patriarch: Palestinian and Babylonian Portrait of a Leader( Tel-Aviv: Hakibbutz Hameuchad, 1999) 263-98 [Hebrew]. On efforts to identify "Antoninus" with a known emperor, see Shaye J. D. Cohen, "The Conversion of Antoninus," The Talmud Yerushalmi and Graeco-Roman Culture (ed. Peter Schäfer; 3 vols.; TSAJ 71, 79, 93; Tübingen: Mohr Siebeck, 1998) 1:141-42; Appelbaum, Dynasty, 40-47.

\footnotetext{
${ }^{34}$ Gen. Rab. 84:3; Lev. Rab. 10:4.

${ }^{35}$ y. Meg. 1:11, 72b; 3:2 74a.

${ }^{36}$ Mek., Shirata 2; Gen. Rab. 34:10.

${ }^{37}$ Mek., Shirata 6; Gen. Rab. 67:6.

${ }^{38}$ y. Šeb. 6:1, 36b; y. Nid. 1:4, 49b = Gen. Rab. 20:6.

${ }^{39}$ Mek., Vayehi Proem; ibid, 1; Gen. Rab. 75:5.
} 
Judah Nesiah and Diocletian, as a result of which a very different perspective on the nature of Roman-Jewish relationship emerges. "Rome" and "Israel" are no longer hypostasized entities destined for eternal conflict. Rather, the Roman-Jewish relationship can be significantly impacted by the agency of both groups' leaders at different points in history. As such, the conflict portrayed between R. Judah and Diocletian was hardly inevitable, but a result of the idiosyncrasies of these two men and likely other historical factors as well.

These various intertextual contexts of our story thus present three different models for understanding the relationship between Rome and Israel that are both complementary and conflicting. The first sees Rome as yet one more in a long line of world-dominating gentile kingdoms that seek to harm the Jews, harkening back to the earliest biblical times. The second presents Rome as having a special status among Israel's oppressors. Rome is both Israel's brother and ultimate enemy. ${ }^{40}$ Finally, the last model does not see the Israel-Edom relationship as necessarily fratricidal. It presents the possibility of fraternal respect and co-operation. Like the biblical Jacob and Esau, the relationship between Israel and Rome can involve embrace and reconciliation as well as deceit and violent conflict.

Read in its broader textual contexts, our story thus envisions the relationship between the Jews and their rabbis on the one hand, and the Romans and their emperors on the other, as complex and deeply fraught with larger implications. The conflict between the Jews and Rome has been foreordained since the beginnings of history. Yet, the story advocates that the Jews pursue not open conflict with the Romans but rather a careful balance of deference to Rome and confidence in their own ultimate triumph. At the same time, the story undermines the notion of eternal enmity between Edom and Israel by subtly invoking the precedent of the friendship between Rabbi and Antoninus. The Edom-Israel typology further suggests that even in conflict, the two nations and their identities are bound together. Both nations are chosen by God as his special agents in history. As the two nations chosen by God to wield true sovereignty, they have more in common than it might first appear.

\section{Part Two: Rabbis as Romans}

The commonality between Rome and Israel to which we have just alluded exists only on the broader historical and metaphysical planes. In my reading of the story thus far, Rome and Israel remain distinct cultural entities and identities, which cannot be confused in any way. This section will explore the ways in which our

\footnotetext{
40 The tension between these two models can be mitigated somewhat by introducing a third narrative-historical framework from the Bible, not directly referenced in our story: Daniel's vision of the four kingdoms. Genesis Rabbah and other rabbinic texts regularly invoke this framework, consistently identifying Daniel's fourth kingdom with Rome. In this scheme, Rome is one of a series of gentile kingdoms that oppress the Jews, but still maintains a privileged place in the divine plan, as the final kingdom whose downfall will usher in the Messianic age. On the four kingdoms motif in Genesis Rabbah and other rabbinic sources, see Rivka Raviv, "The Talmudic Formulation of the Prophecies of the Four Kingdoms in the Book of Daniel” JSIJ 5 (2006) 1-20 [Hebrew].
} 
story breaks down the dichotomy between Romans and Jews on the level of ethos and worldview. Certain aspects and details of the story inscribe ways in which the rabbis very much lived and participated in the wider Roman world. Despite their sense of alienation and opposition to the Romans, the rabbis still shared a common social, cultural and imaginative world with their imperial masters.

\section{A. The Bathhouse}

There is one key feature that both Tiberias and Paneas possess, defying the sharp contrast between the cities presented in the rest of the story: a bathhouse. Roman style bathhouses were a symbol par excellence of the hegemony of Roman culture and a triumph of the transformative power of Roman engineering technology. By the time our story is meant to have taken place, Roman-style bathhouses could be found in virtually every city in the Land of Israel and throughout the Empire. ${ }^{41}$ Their popularity among members of all ethnicities and social groups reflected the deep penetration of Roman values of cleanliness and care of the body throughout the Empire. ${ }^{42}$ Bathhouses were also agents of Roman culture through their décor, which frequently included statues and images drawing on Greco-Roman mythology. As social institutions, the baths brought together people from all walks of life, creating an environment "in which hierarchal, communal and cultural boundaries were-if only for a short while-blurred and even erased." ${ }^{43}$ In sum, the Roman bathhouse "encapsulate[ed] Romanitas: the Roman experience of life." 44 The presence of bathhouses in both Tiberias and Paneas calls attention to the fact that for all their differences, both were Roman cities, named for emperors, which shared many architectural, social, cultural and political features. The Roman city was a common physical and cultural space in which both pagans and Jews lived and throve. ${ }^{45}$

Similarly, the fact that the rabbis in our story enjoy the bathhouse of Tiberias reflects the extent to which the rabbis were indeed engaged in the broader Roman culture. Numerous rabbinic sources attest to the rabbis' intimate knowledge of the baths and regular attendance there. These sources often portray the rabbis in encounters with heretics, pagans, and other individuals who were outside their usual ambit. ${ }^{46}$

${ }^{41}$ Yaron Eliav, "Bathhouses as Places of Social and Cultural Interaction," The Oxford Handbook of Jewish Daily Life in Roman Palestine (ed. Catherine Hezser; Oxford: Oxford University Press, 2010 (עשר שנות מחקר ארכיאולוגי בבאניאס/609-10. On the bathhouse in Paneas, see Vassilios Tzaferis, עיסריה של פיליפוס 12.

${ }^{42}$ Ibid., 606-07. See also Lapin, 127-32.

${ }^{43}$ Eliav, Bathhouses, 614-15.

${ }^{44}$ Ibid., 607.

${ }^{45}$ Indeed, Seth Schwartz (Imperialism, 129-161) argues that Tiberias in this period would have been virtually indistinguishable from a pagan-dominated city in the area.

${ }^{46}$ Eliav, Bathhouses, 608-610. See also, Menachem Hirshman, סיפורי בית המרחץ של טבריה [Stories about the bathhouse of Tiberias], in טבריה: מייסודה עד הכיבוש המוסלמי; Joshua Levinson, "Enchanting Rabbis: Contest Narratives between Rabbis and Magicians in Rabbinic Literature of Late Antiquity," Tarbiz 75 (2005/6) 295-328 [Hebrew]. 
There is also a significant difference between the experiences portrayed at the bathhouses of Tiberias and Paneas. At Paneas, the baths are connected to imperial power and prestige. They are the place where the rabbis are meant to prepare for their audience with the Emperor and where Diocletian intends to wreak his vengeance upon them. The baths of Tiberias, in contrast, are where the rabbis prepare to greet the Sabbath, and they are the sites of the announcement of divine salvation from the clutches of the emperor. This contrast reinforces the dichotomy between Romans and rabbis explored in the previous section. Yet, the fact that rabbis and other Jews adapted the Roman institution of the bathhouse to their particular needs and sensitivities, creating a distinctly Jewish bathhouse experience, ${ }^{47}$ also emphasizes the extent to which rabbinic religious and cultural practices were embedded in their wider Roman milieu.

Unlike the rabbis, numerous church fathers attacked the practice of visiting Roman style bathhouses as decadent and unchristian. ${ }^{48}$ Jerome, a contemporary of the Palestinian Amoraim who spent most of his adult life in the Land of Israel, repeatedly rejected bathing as unnecessary for Christians and a sign of materialism. ${ }^{49}$ Jerome's older contemporary, Epiphanius of Salamis, singled out the baths at Hamat Gader, which the rabbis were known to have frequented, for their licentiousness. ${ }^{50}$ In their acceptance and adoption of this Roman institution, the rabbis were thus more integrated into Roman culture than many of their contemporary Christian counterparts.

\section{B. Daimons}

Several scholars have noted that the appearance of the daimon Argintin in the bathhouse reflects the widespread belief in the Roman world that bathhouses were potentially dangerous places, where magic was practiced and supernatural beings could be found.$^{51}$ Paul Veyne, in his classic text, Did the Greeks Believe in Their Myths?, has taught us that it is not a simple matter to extrapolate a culture's beliefs, especially with regard to supernatural matters, based on the narratives they tell. Indeed, the very concept of "belief" is a slippery one..$^{52}$

Such problems are compounded in our own case by the fact that scholarship on rabbinic demonology has largely focused on the much more plentiful Babylonian material and its contexts. We still do not have a systematic study of intermediary beings in Palestinian rabbinic sources. ${ }^{53}$ Nevertheless, I think it is fair to say that,

${ }^{47}$ Yaron Eliav, "The Roman Bath as A Jewish Institution: Another Look at The Encounter Between Judaism and The Greco-Roman Culture," JSJ, 31 (2000) 416-54.

${ }^{48}$ Ibid., 423-24.

${ }^{49}$ Jerome, Epist. 14.10, 45.4-5.

${ }^{50}$ Epiphanius, Pan., 1.30.7:5-6.

${ }^{51}$ Eliav, "Roman Bath," 430; Levinson, "Enchanting Rabbis," 299-300.

${ }^{52}$ Paul Veyne, Did the Greeks Believe in Their Myths? : An Essay on the Constitutive Imagination (trans. Paula Wissing; Chicago: University of Chicago Press, 1988).

${ }^{53}$ For a bibliography and discussion of the scholarship on Jewish demonology in antiquity, see 
in this instance, the narrative world of our story is largely contiguous with the imaginative world of its authors and original audience. Palestinian rabbis of the Amoraic period did indeed accept the reality of daimons in their world, much as their non-Jewish neighbors did. ${ }^{54}$ The world constructed by our story illustrates how rabbis shared more than physical and cultural spaces with their non-Jewish neighbors. To a significant degree, they shared a common imaginative world as well.

The image of the daimon in our story bears particular affinity to common understandings of intermediary beings among contemporary pagans. In the high imperial era, the term $\delta \alpha i ́ \mu \omega v$ generally referred specifically to intermediary beings between humans and gods. The term was interchangeable with ö $\gamma \gamma \varepsilon \lambda \mathrm{o} s$, which also referred to such beings. ${ }^{55}$ Throughout antiquity, common people perceived divine beings of all levels as behaving fundamentally like humans. They could do good or evil and, hence, could be a help or a hindrance to human beings. Though earlier Greek philosophers rejected the popular idea that divine beings could be a source of evil, over the course of the first- through fourth-centuries $\mathrm{CE}$, neo-Platonic thinkers began to accept the possibility that daimons were not necessarily purely good, but could be malicious as well.

Early Christian thinkers also posited the existence of both good and evil intermediary beings. However, whereas in pagan thought and culture of the time, all intermediary beings belonged to the same class of "daimons," with the potential to do good or evil, Christians made a very clear distinction between two classes of intermediary beings. It is in early Christian literature that the term "daimon" first takes on its diabolical implications, referring specifically to supernatural agents of evil, opposed to angels. "Daimons" become "demons," servants of Satan. ${ }^{56}$ Angels and demons "were not just ontologically different, variant in their natures, but also morally different. [While h] uman beings were morally ambivalent, angels [were] good, and demons evil." ${ }^{57}$ It is difficult to imagine a Christian narrative that features an intermediary being with an ambiguous status and the potential for both good and evil. ${ }^{58}$

Sara Ronis, "Intermediary Beings in Late Antique Judaism: A History of Scholarship," CBR 14 (2015) 94-120.

${ }^{54}$ My use of the phrase "accept the reality of," as opposed to "believe in," is inspired by Ellen Muehlberger's discussion in her Angels in Late Antiquity (Oxford: Oxford University Press, 2013) $18-19$.

${ }^{55}$ Muehlberger, Angels, 52.

${ }^{56}$ This account is synthesized from Dale Martin, Inventing Superstition: From Hippocrates to the Christians (Cambridge, MA: Harvard University Press, 2004), and Sharon L. Coggan, Pandaemonia: A Study of Eusebius' recasting of Plutarch's story of the "Death of Great Pan" (PhD diss., Syracuse University, 1992) 108-93.

${ }^{57}$ Muehlberger, Angels, 30.

${ }^{58}$ It should be noted that, as Muehlberger demonstrates in her book, ancient Christians subscribed to a wide variety of understandings of the nature and role of angels and demons. Nevertheless, as is clear from Muehlberger's account, there was a broad consensus among early Christians as to the fundamental dichotomy between angels and demons. 
As this background makes clear, the figure of Argintin in our story is much more consistent with the ambivalent pagan understandings of intermediary beings than the starkly dualistic Christian vision of angels and demons. ${ }^{59}$ At first, R. Judah identifies Argintin as a malevolent force, but he subsequently learns from R. Samuel that Argintin can also be a harbinger of salvation, as turns out to be the case in this instance. We might easily classify Argintin as a daimon in the traditional pagan sense, but he defies categorization in the Christian scheme of angels and demons. At least with regard to this important issue, the world as imagined by our rabbinic authors was closer to that of the pagans throughout the Empire than it was to that of their Christian neighbors.

\section{Argintin}

The question of the identity of Argintin,,$^{60}$ the supernatural intercessor, remains. Thus far, we have identified him simply as a "daimon." Sokoloff translates the name simply as "a type of demon," stating that the origin of the name is unknown. ${ }^{61}$ Theodor and Albeck, following the medieval lexicon, the Arukh, similarly explain the term as a "demon of the bathhouse," deducing the daimon's abode from the context of the story. ${ }^{62}$ In light of the fact that this name would appear be of Greek origin, two other lexicographers have sought to identify the figure of Argintin with a figure from classical mythology and folklore. Jastrow postulates that the term

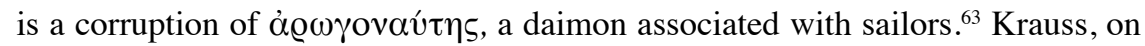
the other hand, identified him with $\alpha \varrho \gamma \eta \dot{\tau}\rceil 5$, "a name for lightning and one of the Cyclopes." ${ }^{64}$ Neither of these suggestions particularly fits the character who appears in our story.

I would like to suggest another etymology for the name. The terms ày@ev́s and $\alpha \gamma \varrho o ́ \tau \alpha$, meaning "hunter," can serve as epithets for Pan, the Greek god

${ }^{59}$ On the commonalities between rabbinic and early Christian demonology see, Ishay Rosen-Zvi, "'Yetser ha-ra' and 'Daimones': A Shared Ancient Jewish And Christian Discourse," in Jews and Christians in the First and Second Centuries (ed. Peter Thomson and Joshua Schwartz; CRINT 13; Leiden: Brill, 2014) 431-53.

60 ארגינט whe in the first appearance of the word (101v). The second appearance in Vatican 30 (102r) as well as the first appearance in Vatican 60 read ארגינטי. MS Oxford 147 reads ארגנט. Editio Princeps (Constantinople, 1512) reads , hence my vocalization. However, in the second appearance of the word, several witnesses read the first three letters as ארג rather than: Theodor-Albeck, following MSS London and

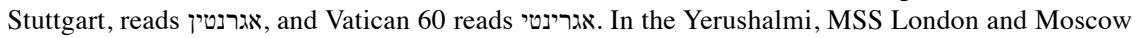
read ארגינטיטריס whereas Leiden reads, with the other MSS presenting variants of this reading.

${ }^{61}$ Michael Sokoloff, A Dictionary of Jewish Palestinian Aramaic of the Byzantine Period (Baltimore: Bar Ilan University Press and Johns Hopkins University Press, 2002) s.v. ארגינט see also s.v. אנגיטריס.

${ }^{62}$ Theodor and Albeck, בראשית רבא, 689 n. 4.

${ }^{63}$ Marcus Jastrow, A Dictionary of the Targumim, The Talmud Babli and Yerushalmi and the Midrashic Literature (London: Luzac and Putam, 1903) s.v. ארוגנוטין.

${ }^{64}$ Samuel Krauss, Griechische und Latinische Lehnwörter im Talmud, Midrasch und Targum (Berlin: Calvary, 1899) s.v. ארגינטין. 
of hunters and shepherds. ${ }^{65}$ They appear in this context in several epigrams and inscriptions. ${ }^{66}$ Most significantly for our purposes, there are two late antique sources that establish the use of this term as a name for Pan in the same time period and in rough geographic proximity to the authors and editors of Genesis Rabbah. The fifth century lexicographer, Hesychius of Alexandria, defines 'A $\gamma \varrho \varepsilon v ́ \varsigma$ sas the Athenian name for Pan. ${ }^{67}$ The other source is a passage from Nonnos's Dionysiaca, a late Greek epic completed in the late fourth- or early fifth-century in Egypt, which recounts the adventures of Dionysus. Book fourteen of the epic lists the members of the host with which Dionysus marches east to do battle in India. Among those who follow Dionysus are a series of incarnations of the god Pan:

The rock dwellers came also from their self-vaulted caves, bearing all the name of Pan ... all armed to join the host; they have human form, and a shaggy goat's head upon it with horns. Twelve horned Panes there were, with this changeling shape and horn bearing head, who were begotten of the one ancestral Pan their mountain ranging father . . . Then there was Argos

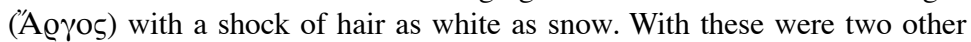
Panes, the sons of Hermes, who divided his love between two Nymphai; for once he visited the bed of Sose, the highland prophetess, and begat a son inspired with the divine voice of prophecy, Agreus ('A $\gamma \varrho \varepsilon ́ \alpha$ ), well versed in the beast-slaying sport of the hunt; the other was Nomios, whom the pasturing sheep loved well, one practiced in the shepherd's pipe, for whom Hermes sought the bed of Penelope the country Nymphe. Along with these came Phorbas (Fear) to join their march, savage and insatiate. ${ }^{68}$

Here we see a proliferation of Panes, with Agreus representing Pan's role as patron of hunters. Among the twelve-horned Panes who are mentioned before Agreus and his brother is also a "Pan" named Argos. I would like to suggest that the name Argintin, or Agrinti[n] in some witnesses,${ }^{69}$ is a corruption of some form

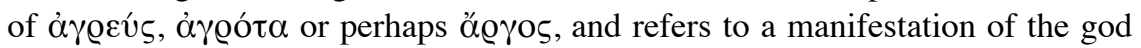
Pan. This identification of Argentin with Pan is supported by the description in the midrash of him as dancing and laughing. "Dance and music are among Pan's most

${ }^{65} P W 1,1: 891$, s.v. "Agreus," definition number 2; William Smith, A Dictionary of Greek and Roman Biography and Mythology (3 vols.; London: John Murray, 1880) 1:75, s.v. "Agreus." It should be noted that this appellation and related forms can sometimes refer to other gods as well.

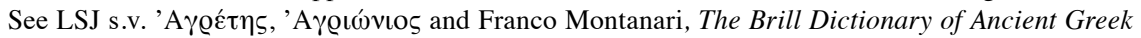

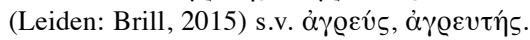

${ }^{66}$ See The Greek Anthology (trans. W.R. Paton; 5 vols.; LCL 67-68, 84-86; Cambridge, MA: Harvard University Press, 1969) 1:305 and 391; Georgius Kaibel, Epigrammata graeca ex lapidibus conlecta (Berlin: Reimer, 1878) 498, epigram 1104.

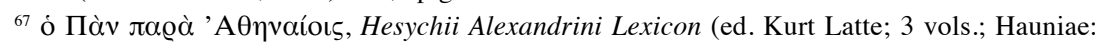
Munksgaard, 1953) 1:30, s.v. A $\gamma$ ozús.

${ }^{68}$ Nonnos, Dion. 14.67-95, (Nonnos, Dionysiaca: Books 1-15 [trans. W. H. D. Rouse; LCL 344; Cambridge, MA: Harvard University Press, 1962] 476-79).

${ }^{69}$ See above n. 60 . 
fundamental traits," ${ }^{70}$ and Pan was also closely identified with laughter. ${ }^{71}$ These two activities played key roles in the practice of his cult. ${ }^{72} \mathrm{Pan}$ is identified in the Dionysiaca as being a swift runner, like his father, Hermes. ${ }^{73}$ This could explain Argentin's ability to transport the rabbis from Tiberias to Paneas with such speed. Pan's status as a guide of travelers also fits in well with our story. ${ }^{74}$ Pan's overall image in the classical world was one of ambiguity and liminality. "He is both the Good Shepherd and protector of the flocks, and at the same time merges with their greatest enemy, the wolf . . . at once benevolent protector and savage predator." 75 Similarly, in our story Argentin is both a potential harbinger of doom and ultimate bearer of salvation. Of course, the clearest link between Pan and our story is the centrality of the city of Paneas, named for the god and site of his shrine.

If this interpretation is correct, it has significant implications for understanding our story. In the semiotic structure of the story, Argentin/Pan at first appears to fall on the side of Paneas, Diocletian, and the Romans. As the patron god of Paneas, he stands at the top of the list, representing the Greco-Roman gods. He is parallel to God himself on the side of Tiberias, R. Judah, and the Jews. As we have seen, as part of his efforts to consolidate the power of the Emperor, Diocletian initiated a revival of the cults of the old Greco-Roman gods. Gods such as Pan, then, would have been closely associated with imperial power at the time and with Diocletian in particular. This would explain R. Judah's initial negative response when Argentin first appears. R. Judah naturally assumes that Argentin is on the side of the Emperor and the Romans who worship him. But in an ironic reversal, Argentin turns out to be a double agent. He really serves God and executes his plan to save the rabbis miraculously. The theme of God's protecting his people is now strengthened and contains a strong polemical aspect. As we have seen, the Romans believed that their temporal success was a sign that they were favored by their gods. The story teaches us that, in fact, the Greco-Roman gods are completely subservient to the God of Israel. Roman power ultimately depends on God, who will never abandon the Jews. ${ }^{76}$

But the appearance of Argentin/Pan has even broader implications. The identification of Argentin with Pan would make our story the only instance of which I am aware in which a Greco-Roman god appears as a character in a rabbinic story. This further exacerbates the problem of the relationship between the world of our

${ }^{70}$ Phillippe Borgeaud, The Cult of Pan in Ancient Greece (trans. K. Atlas and J. Redfield; Chicago: University of Chicago Press, 1988) 86. For further references to Pan's dancing, see 53, 55.

${ }^{71}$ Ibid., 236 n. 105. For further references to Pan's laughter, see 54, 107.

${ }^{72}$ Ibid., 150.

${ }^{73}$ Nonnos, Dion. 5.297 (LCL 344: 190-91). See also Borgeaud, Cult of Pan, 153.

${ }^{74}$ Robin Lane Fox, Pagans and Christians (New York: Knopf, 1986) 130.

${ }^{75}$ Coggan, Pandaemonia, 87-88.

${ }^{76}$ This runs counter to Saul Lieberman's claim that, unlike ancient Christian and Jewish Hellenistic polemics against idolatry, the rabbis attack idolatry in general but "do not denounce the Greek gods specifically" (Hellenism in Jewish Palestine [New York: Jewish Theological Seminary, 1950] 118). 
story and the worldview of its authors. Did the rabbis "believe" in the existence of the great god Pan? It is possible to interpret our story as a satirical polemic which in no way posits the reality of the gods ${ }^{77}$ But the stories the rabbis tell about themselves and their rabbinic predecessors, no matter how fantastic at times, are not presented as being fictional in any way. ${ }^{78}$ The simplest explanation of our story would appear to be that these particular rabbinic authors did in fact assume the reality of Pan and presumably the other Greco-Roman gods as well. Still, in their imagination, these beings were not independent divine actors. Rather, they were lesser supernatural beings, ultimately bound by the divine will, no different from other daimons who populated their landscape.

To my knowledge, there is no parallel elsewhere in rabbinic literature that shares such an approach to pagan deities. However, this approach does have roots in the Bible and Second Temple era literature. ${ }^{79}$ A similar approach was taken by some contemporary middle Platonist philosophers, who re-classified at least some of the Greco-Roman gods as daimons in order to distinguish them from the eternal, unchanging god of Plato. In a well-known passage, Plutarch cites a report that in the days of the emperor Tiberius, a voice was heard declaring, "Great Pan is dead." Plutarch uses this tradition to prove that Pan, and by extension the other gods as well, were mortal and hence must be daimons rather than true gods. ${ }^{80}$ In this way, the imaginative world presented in our story proves to be quite similar to that of some contemporary non-Jewish thinkers.

The notion that the pagan gods were in fact intermediary beings was widely accepted by early Christians as well. ${ }^{81}$ In the Christian framework, though, the pagan gods were identified as "demons," servants of Satan who were in eternal conflict with God and Christ. This approach cast the Christian struggle against paganism as a cosmic conflict between the forces of good and evil, quite literally demonizing their opponents. Yet, at the same time, it also affirmed the reality of the gods as potent forces in the world. The early Christians did not dismiss the pagan gods as powerless figments of idolaters' imaginations, as did many of the Hebrew

${ }^{77}$ On such parodies in rabbinic literature and ancient literature in general, see Joshua Levinson, "Fatal Charades and the Death of Titus," Jerusalem Studies in Hebrew Literature 19 (2003) 23-45 [Hebrew].

${ }^{78}$ See Moshe Simons-Shoshan, Stories of the Law: Narrative Discourse and the Construction of Authority in the Mishnah (Oxford: Oxford University Press, 2012) 7.

${ }^{79}$ See Israel Knohl, "Biblical Attitudes to Gentile Idolatry," Tarbiz 64 (1994) 5-12 [Hebrew]; Michael Segal, "Who is the "Son of God' in 4Q246?" DSD 21 (2014) 289-312; idem, The Book of Jubilees: Rewritten Bible, Redaction, Ideology and Theology (JSJSup 117; Leiden: Brill, 2007) 240-44. Of particular interest for our purposes is Ps 96:5 and the LXX there (95:5), which translates

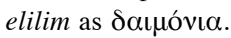

${ }^{80}$ Plutarch, Def. orac. 17.

${ }^{81}$ Fox, Pagans and Chritians, 137; Coggan, Pandaemonia, 162-170. For the sources and theological context of these beliefs, see Jean Daniélou, A History of Early Christian Doctrine Before the Council of Nicaea, Volume Two: Gospel Message and Hellenistic Culture, (trans. and ed. John Austin Baker; Philadelphia: Westminster Press, 1973) esp. 17-18, 183-94, 434-36. 
prophets. The Christian belief that the gods were in fact demons allowed them to participate in the wider Greco-Roman worldview in which the gods, particularly Pan, continued to be a vital presence in the world without compromising their belief in the sovereignty of God and his Christ. ${ }^{82}$

Among the most prominent Christian advocates of the notion that the pagan gods were really demons was Eusebius of Caesarea. As the leading churchman of the Land of Israel in the time of Diocletian and Constantine, his writings are of particular interest here. In his polemics against paganism, Eusebius repeatedly focuses on Pan. Previously, we noted Plutarch's report of a voice that was heard during the reign of the Emperor Tiberius declaring the death of Pan. Eusebius appropriates this account to fit his own narrative about the gods and demons. He explains Plutarch's mysterious voice as declaring the overthrow of all pagan gods/ demons at the hand of Christ, whose ministry occurred during the reign of Tiberius. ${ }^{83}$

In his Church History, Eusebius presents a story that parallels our own rabbinic narrative. It too is set in Paneas and involves an encounter between a daimon and a holy man. Eusebius's story is worthy of consideration here because it throws into relief some of the distinctive elements of our rabbinic authors' efforts to negotiate their relationship with Roman hegemony. Eusebius's account stars Astyrius, who was "a Roman of senatorial rank, and in favor with the emperors, and well known to all on account of his noble birth and wealth." ${ }^{84}$ He was martyred for his Christian activities at Caesarea Maritima in the mid-third century. ${ }^{85}$ After telling the story of Astyrius's martyrdom, Eusebius relates:

At Caesarea Philippi, which the Phoenicians call Paneas, springs are shown at the foot of the Mountain Panius, out of which the Jordan flows. They say that on a certain feast day, a victim was thrown in, and that through the power of the demon it marvelously disappeared and that which happened was a famous wonder to those who were present. Astyrius was once there when these things were done, and seeing the multitude astonished at the affair, he pitied their delusion; and looking up to heaven he supplicated the God over all through Christ, that he would rebuke the demon who deceived the people, and bring the men's delusion to an end. And they say that when he had prayed thus, immediately the sacrifice floated on the surface of the fountain. And thus the miracle departed; and no wonder was ever afterward performed at the place. ${ }^{86}$

As Wilson argues, this story is best understood as taking place in the pool inside the sacred cave of Pan and telling of a sacrifice (likely a goat) to the god ${ }^{87}$ For

${ }^{82}$ Fox, Pagans and Chritians, 130.

${ }^{83}$ Eusebius, Praep.ev. 5.17. Coggan, Pandaemonia, is entirely devoted to an explication of this passage and of Eusebius's understanding of gods as demons.

${ }^{84}$ Eusebius, Hist. eccl. 7.16 (NPNF ${ }^{2}$ 1, digital version at Christian Classics Ethereal Library, http://www.ccel.org/ccel/schaff/npnf201).

${ }^{85}$ Ibid.

${ }^{86}$ Ibid., 7.17.

${ }^{87}$ Wilson, Caesarea, 85-86. 
Eusebius, Pan is a malevolent force who seeks to deceive the people into worshiping him instead of God and Christ. ${ }^{88}$ The story is one of a direct conflict between Christ and the demon, in which Christ triumphs over the forces of evil. Eusebius thus portrays the battle of later Christian holy men against idolatry as a continuation of Jesus's mission to cast out the demons from this world and as part of an ongoing war of good against evil, pitting Christian civilization in mortal combat against the pagan culture of Rome.

There is a fundamental connection between the worldviews presented in these two Paneas narratives. Both stories depict their authors' respective religious communities as simultaneously participating in the Roman world and holding themselves apart from it. Eusebius and our rabbinic authors accept the reality of the Greco-Roman gods, thereby reconciling themselves to aspects of the contemporary pagan worldview. They also recast their respective group conflicts with Rome and its culture as part of an ongoing struggle of eschatological significance. For Eusebius it is the battle between Jesus and Satan, whereas for the rabbis it is the ongoing conflict between Israel and the nations, particularly Edom.

The critical differences between the two stories can be highlighted by contrasting two sets of parallel characters in the story. First, there is the figure of Pan/Argentin. In Eusebius's account, the god is the implacable enemy of the Christians and their God. For the authors of our story, Pan/Argentin is an ambiguous trickster who, like all creation, is ultimately subservient to the divine will. They reject Eusebius's dualism, taking a monistic approach in line with mainstream rabbinic theology. In this way, the rabbinic story constructs a world that is closer to that of pagan philosophers like Plutarch than that of Christians such as Eusebius.

Both stories also present characters who are Roman aristocrats of the highest level. Diocletian is the embodiment of Rome and Romanness. The tension between him and R. Judah remains in place throughout the story. The story offers no possibility of bridging the gap between Israel and Edom. On the other hand, Eusebius presents Astyrius as both a Roman aristocrat of the highest rank and a Christian martyr and miracle worker. Astyrius pre-figures the conversion of Constantine and the Empire itself in Eusebius's own day. For Eusebius, the Empire was not ultimately opposed to the Church, as they were destined to merge into a single entity. ${ }^{89}$

There is thus something of an inverse relationship between these two worldviews. On the political and ethnic levels, the rabbis see Israel as a nation apart, which will never be truly Roman, whereas Eusebius sees the Church as destined to become one with the Romans and their Empire. On the metaphysical level, however, Eusebius sees an absolute dichotomy between the God of the Christians and the gods of the Romans. In contrast, the rabbinic authors of our story present a more

\footnotetext{
${ }^{88}$ See also, Eusebius, Praep.ev. 3.11, 14; 5.6-7.

${ }^{89}$ On Eusebius's integration of imperial ideology with Christian theology, see Martin, Superstition, 222-26.
} 
ambiguous relationship between the God of Israel and these same gods, holding out the possibility of these gods serving God and his people.

It is important to emphasize that even if this ultimately speculative identification of Argentin with Pan is correct, we cannot extrapolate the story's acceptance of the reality of the Greco-Roman gods beyond this text. Most rabbinic literature takes a strictly monotheistic view, which denies any realty to the gods of the nations. At most, our story establishes the outside limit of the ways in which rabbinic texts display accommodation with and assimilation of said views into their larger cultural context. Yet, there can be no doubt that Argentin is, in fact, a daimon who serves God rather than opposes him. Even if our story does not relate to the pagan gods, it certainly rejects Christian dualistic demonization of the supernatural forces whose existence was accepted by all in the late antique world. This view is in line both with rabbinic monism and ideas in the wider pagan culture regarding intermediary beings. In our narrative, the figure of the daimon does not serve to emphasize the conflict between the biblical monotheists and the dominant culture, as it does in Eusebius's story, but rather calls attention to their commonalities.

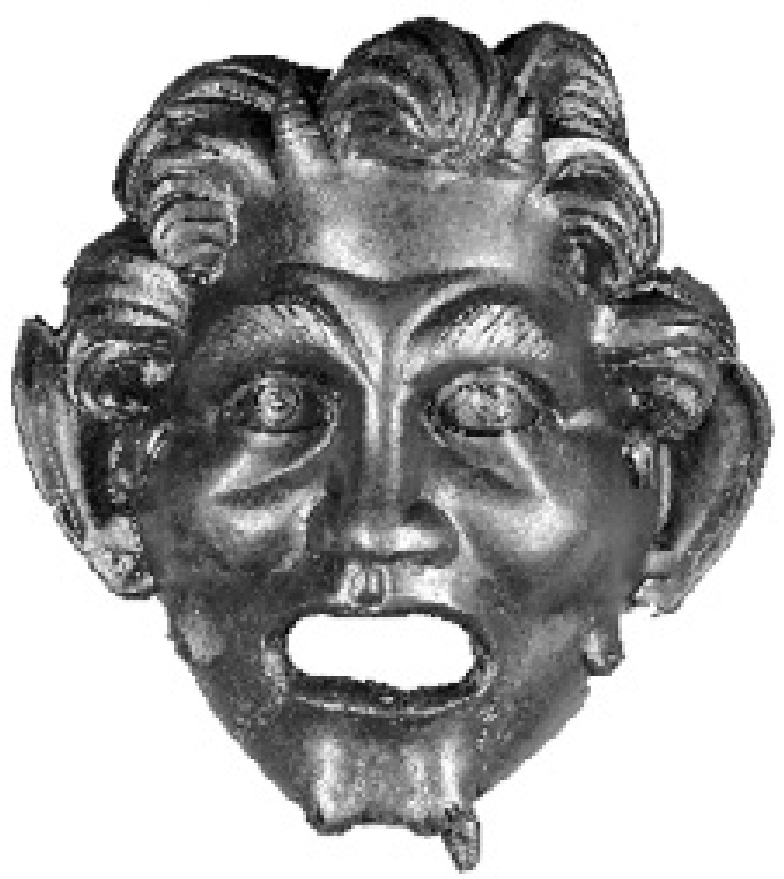

Bronze mask of Pan, late first to early second century C.E., discovered in 2014 at Hippos in the Golan Heights. Photo courtesy of Michael Eisenberg, Zinman Institute of Archaeology, Haifa University. 


\section{Conclusion}

The story of Rabbi Judah Nesiah's encounter with Diocletian presents a complex picture of the ways in which the rabbis conceptualized and negotiated their relationship with Roman political and cultural hegemony. On a fundamental, structural level, the story presents a sharp dichotomy between the conflicting worlds and values of the rabbis and those of the Roman Empire. This conflict is embedded in multiple and, to some degree, mutually exclusive hermeneutical and meta-historical frameworks. The struggle between Rome and the Jews is framed in terms of the biblical conflicts between Israel and the non-Jewish kingdoms that were sent by God to oppress and punish it. In particular, this conflict is an extension of the eternal quarrel between Israel and Edom. Yet, our story also implicitly invokes the more contemporary example of the friendship between Rabbi Judah Hanasi and Antoninus, suggesting that conflict between the two nations is not inevitable and that cooperation between them is still possible. Furthermore, these models, especially the Israel-Edom typology, confirm the "chosenness" of Rome and the existence of a special bond which unites Jews and Romans, distinguishing them from other peoples.

The sense that Jews and their rabbis have more in common with the Romans than it may at first appear becomes even stronger as we investigate the story's imagery of the bathhouse and the daimon Argentin. The practices and beliefs of the rabbis with regards to bathhouses and daimons were quite Roman in ways that those of their Christian contemporaries were not. Finally, I have argued that the daimon Argentin is to be identified with none other than the great god Pan, implying that the authors of our story accepted the reality of the Greco-Roman gods in the guise of lesser daimons subservient to the Almighty. This belief parallels those of some contemporary pagan philosophers and contrasts sharply with the Christian demonization of pagan gods.

Our story emerges as a site in which varying perspectives on the dominant political, cultural, and metaphysical power structures in late antique Palestine engage with one another. It presents a tension between the sense of continuous, intractable conflict between the Jews and the broader Roman world and the ways in which the Jews, the rabbis among them, were very much part and parcel of that world. 